\title{
LITIGATING CROSS-BORDER ENVIRONMENTAL DISPUTE IN INDONESIAN CIVIL COURT: THE MONTARA CASE
}

\author{
Iman Prihandono* and Esty Hayu Dewanty R.K.**
}

\begin{abstract}
* Head of Department International Law Department, Faculty of Law, Universitas Airlangga
** Junior Lecturer at Department of International Law, Faculty of Law Universitas Airlangga
\end{abstract}

\section{Article Info}

Received : 19 January 2015 | Received in revised form : 13 April 2015 | Accepted : 13 April 2015

Corresponding author's e-mail : iprihandono@fh.unair.ac.id; esty@fh.unair.ac.id

\begin{abstract}
In August 2009, a wellhead blowout of took place at an offshore drilling facility named the Montara platform, on the north coast of Australia. This incident released crude oil into the sea and continued until November 2009. The Montara platform is owned by PTTEP Australasia Pty. Ltd., a company incorporated under the law of Australia, and a subsidiary of PTT Exploration and Production Public Company Limited, a Thailand based, state-owned oil company. Based on samples taken by the East Nusa Tenggara Municipality in the waters along the coast of Kolbano, it was found that the sea water has been polluted with crude oil. There was an indication that the crude oil was identical to those of at the Montara well head platform. This incident has been detrimental to at least 9.000 fishermen and seaweed farmers along the coast of West Timor Sea, with total losses estimated at USD2.4 billion. This article examines the possibility of a lawsuit brought by the affected communities to the Indonesian civil court. This article finds that filing a lawsuit against foreign entity may be possible. Article $100 \mathrm{RV}$ of the Indonesian law on civil procedure provide an opportunity to sue foreign entity when a contractual relationship exists.
\end{abstract}

Keywords: trans boundary sea pollution, transnational litigation, indonesian court.

\begin{abstract}
Abstrak
Pada Agustus 2009, terjadi kebocoran pada fasilitas pengeboran lepas pantai di pantai utara Australia, yang diberi nama Montara. Kebocoran ini menumpahkan minyak mentah ke laut dan berlanjut sampai dengan Nopember 2009. Fasilitas pemngeboran Montara dioperasikan oleh PTTEP Australasia Pty. Ltd., sebuah perusahaan Australia, dan anak perusahaan dari PTT Exploration and Production Public Company Limited, yang merupakan perusahaan milik negara Thailand. Berdasarkan sampel yang diambil oleh pemerintah daerah Nusa Tenggara Timur pada perairan pantai Kolbano, ditemukan bahwa perairan laut telah tercemar oleh minyak mentah. Terdapat indikasi kuat bahwa minyak mentah ini identik dengan yang ditemukan pada fasilitas pengeboran Montara. Kejadian ini telah merugikan 9.000 nelayan dan petani rumput laut di sepanjang pantai Timor Barat, total kerugian diperkirakan USD2.4 milyar. Tulisan ini menguji kemungkinan bagi masyarakat korban membawa kasus ini ke pengadilan perdata Indonesia. Tulisan ini menemukan bahwa terbuka kemungkinan menggugat badan hukum asing. Pasal $100 \mathrm{RV}$ hukum acara perdata Indonesia memungkinkan menggugat orang asing bila terdapat hubungan perikatan.
\end{abstract}

kata kunci : polusi laut lintas-batas, litigasi lintas-negara, pengadilan indonesia. 


\section{Introduction}

In August 2009, a wellhead blowout took place at an offshore drilling facility of Montara platform, on the north coast of Australia. This incident released crude oil into the sea and continued until November 2009. The Montara platform was operated by PTTEP Australasia Pty. Ltd. (PTTEP AA), a company incorporated under the law of Australia, and is a subsidiary of PTT Exploration and Production Public Company Limited (PTTEP PCL), a Thailand's state-owned energy company.

Based on samples taken by the East Nusa Tenggara Municipality in the waters along the coast of Kolbano, Desa Tuafanu, District Kualin, South Central Timor, it was found that the sea water has been polluted with crude oil. ${ }^{1}$ There has been an indication that the oil substance is identical to those of at the Montara Platform. This incident has been detrimental to at least 9.000 fishermen and seaweed farmers along the coast of West Timor Sea, with total losses estimated at USD 2.4 billion. $^{2}$

This article examines the possibility of a lawsuit brought by the affected communities to Indonesian civil court. This article seeks to map the possibilities should the victims decide to bring this case to the court. It aims at assisting the victims in preparing their case and obtaining the best outcome for their remedy.

Section II presents a brief overview of the oil spill incident, its impact, and the compensation requested by the Indonesian government. Section III discuses the recent development of the cases, the measures taken by Australian government and the company. It also provides a brief discussion of the possible alternatives forum for the victims to obtain relief. In Section IV, analysis on the subject matter jurisdiction of the Indonesian civil court is presented. This is followed by analysis on the possible parties involved in the dispute. Section $V$ examines the possible burdens which may occur when litigation environmental disputes in Indonesian civil court. This is followed by conclusion in Section VI.

This article finds that filing a lawsuit against PTTEP AA, the operator of the Montara Platform, may be possible. Article $100 \mathrm{RV}$ of the Indonesian civil procedure provides an opportunity to sue foreign entity when contractual relationship exists. In Montara case, contractual relationship exists because there is a violation to Indonesian law. This violation creates an obligation to PTTEP AA to compensate the victims and to restore the environment. There are two possible lawsuits in this case. The first is lawsuit based on the legal standing of environmental NGOs, and the second is lawsuit based on class action mechanism. However, there is at least one crucial challenge for the plaintiffs. They must establish the causal link between the damage suffered and the oil pollution. This requirement in particular would be the most difficult challenge to be tackled by the plaintiffs. This is because substantial evidences may have disappeared, considering that five years have elapsed since the incident was first took place.

\section{Brief Overview of the Case}

In Friday 21 August 2009, the Montara wellhead platform located 140 nautical

1 The Jakarta Post (1), “West Timor Sea Contaminated by Oil Spill," http://www.thejakartapost. com/news/2009/10/28/west-timor-sea-contaminated-oil-spill.html, accessed 15 September 2014.

2 The Jakarta Post (2), "RI to Make Formal Claim in Timor Spill," http://www.thejakartapost.com/ news/2010/08/24/ri-make-formal-claim-timor-spill.html, accessed 20 September 2014. 
miles (approximately 260 kilometers) offshore from the northwest Australian coast had an uncontrolled release of hydrocarbons from one of the platform wells. ${ }^{3}$ Consequently, oil escaped to the surface and gaseous hydrocarbons escaped into the atmosphere. The oil spill resulted in the activation of the National Plan program, managed by the Australia Maritime Safety Authority (AMSA). ${ }^{4}$

The estimation provided by the operator, PTTEP AA was that 400 barrels (or approximately 64 tones) of crude oil were lost per day. It was the longest and in most complex oil spill response operation since the National Plan was established in 1973. The uncontrolled release continued until 3 November 2009 and response operations continued until 3 December 2009. ${ }^{5}$

On behalf of the local community, The Government of Indonesia is seeking USD 2.4 billion in compensation from PTTEP AA following the Montara oil spill incident. The Indonesian government claims that fishing grounds in the Timor Sea were polluted and the fishing number fell significantly as the result of the spill, and inshore seaweed fishermen (particularly on the island of Rote) suffered from the lost of their living sources. ${ }^{6}$ Furthermore, The West Timor Care Foundation, which supports poor fishermen in eastern Indonesia, estimated the spill affected the livelihoods of about 18.000 fishermen. Businesses such as seaweed and pearl farms were also hardly hit by the incident. ${ }^{7}$

Spies, the chief scientist for the Exxon Valdez Oil Spill Trustee Council, and who served as an adviser to US government after the BP Deepwater Horizon disaster in 2010, stated that the Timor Sea can still be restored, but only with 'serious attempts' made by the Indonesian and Australian governments in coordination with the company who operated the Montara Platform. Furthermore, Spies studied the impact of the Montara spill in the Timor Sea, particularly in Indonesian waters. He found that the pollution caused by the Montara well head blowout is just as severe as the Gulf of Mexico spill. ${ }^{8}$

\section{Recent Development of the Case}

In November 2009, the Minister for Resources and Energy Australia established a Commission of Inquiry to report on the uncontrolled release of hydrocarbons at the Montara wellhead platform and subsequent events. The inquiry is required to report by the end of June 2010 and is being undertaken pursuant to Part 9.10A of the Offshore Petroleum and Greenhouse Gas Storage Act 2006 (OPGGS Act) which relates

\footnotetext{
${ }^{3}$ Australian Maritime Safety Authority, "Response to the Montara Wellhead Platform Incident: Report of the Incident Analysis Team," (report by the Incident Analysis Team into the Response by the National Plan to Combat Pollution of the Sea by Oil and Other Noxious and Hazardous Substances, to the Montara Wellhead Platform Incident, March 2010), p. v, http://www.amsa.gov.au/forms-and-publications/publications/montara_iat_report.pdf, accessed 10 September 2014.

4 Ibid, p. 5.

5 Ibid.

6 PTTEP Australia (1), "Fact Sheet: Government of Indonesia Compensation Claim,” http://www. au.pttep.com/media/20778/government\%20of\%20indonesia\%20compensation\%20claim.pdf, accessed 10 September 2014.

7 The Jakarta Globe, “2009 Timor Sea Oil Spill : Just as Devastating as Gulf of Mexico," http://www. thejakartaglobe.com/archive/2009-timor-sea-oil-spill-just-as-devastating-as-gulf-of-mexico/, accessed 8 September 2014.

8 Ibid.
} 
to inquiries into significant offshore incidents. ${ }^{9}$

Moreover, the Australian Government, in conjunction with PTTEP AA, developed a long-term environmental monitoring program to understand the longer term impacts of the spill on the marine environment. ${ }^{10}$ This program which is known as the 'Monitoring Plan for the Montara Well Release Timor Sea', consists of five operational monitoring studies-which were implemented during the response to the incident, and seven scientific monitoring studies. The implementation of the scientific studies is determined by information provided by the operational studies and components of other scientific studies. ${ }^{11}$

Experts from the Australian Institute of Marine Science and relevant state and territory agencies provided input into the plan and its implementation to ensure that the monitoring program is appropriate and robust. This plan covers both short-term and long-term environmental effects of the Montara oil spill, including marine life surveys, wildlife and habitat studies, continous water quality testing and shoreline ecological assessments. ${ }^{12}$

In August 31, 2012, PTTEP PCL was fined USD 526.320 (AUD 510.000) for its negligence in relation to the disaster. The company was found guilty on four charges by the Darwin Magistrate. The first three charges, each of which carries a maximum penalty of USD 567.000 (AUD 550.000), fall under Clause 9(4) of the OPPGS Act 2006. The fourth charge, which carries a maximum penalty of USD56.760 (AUD 55.000), lies under Section 569(1) of the OPPGGS Act, which relates to the failure to ensure that operations were conducted 'in a proper and workman-like manner and in accordance with good oilfield practice'.13

\section{Possible Means for Dispute Settlement}

In 1992 Australia ratified the International Convention on Oil Pollution Response and Co-Operation (OPRC). ${ }^{14}$ This particular instrument covers oil pollution at sea which is caused by offshore facilities that conduct a gas and oil exploration and exploitation..$^{15}$ It provides a mechanism for cooperation between states in responding to oil pollution at sea. Furthermore, this instrument imposes obligations to the state to establish response mechanism and appoint an authority to mitigate oil pollution incidents. ${ }^{16}$ It also imposes obligation to member states to immediately inform other states that may be potentially affected by the incidents. ${ }^{17}$

However, for a number of reasons, the above international convention may not be applied for the allegation of oil pollution at the Timor Sea. First, the OPRC does not impose any obligation for the States where the oil substance is originating to

\footnotetext{
9 Australian Maritime Safety Authority, op.cit., p. vii.

${ }^{10}$ Australian Government Department of the Environment, "Montara Oil Spill," http://www.environment.gov.au/topics/marine/marine-pollution/montara-oil-spill, accessed 8 September 2014.

${ }^{11}$ Ibid.

12 Ibid.

${ }^{13}$ Rigzone, “PTTEP Fined Over $\$ 500,000$ for Montara Oil Spill Disaster," http://www.rigzone.com/ news/article.asp?a_id=120382, accessed 11 September 2014.

14 Convention on Oil Pollution Response and Co-Operation (OPRC) is entered into force 13 May 1995.

15 Convention on Oil Pollution Response and Co-Operation (OPRC), London, 30 November 1990, United Nations Treaty Series, No. 51, 30 ILM 733, art. 3(2).

${ }^{16}$ Ibid., art. 6.

17 Ibid., art. 5.
} 
compensate any damage suffered by other states affected by such pollution. The convention aims only at accommodating the sharing of information, joint action and cooperation between States in mitigating oil pollution incidents. Second, States should bear its own expenses in taking action to respond to the oil pollution incidents, unless there is a specific financial arrangement between the States in concern. ${ }^{18}$ Unfortunately, there is no agreement between Australian and Indonesian government regarding this issue.

Third, Indonesia has not ratified the OPRC, therefore it may not be able to submit its allegation on the violation of OPRC by the Australian government. Though it is not possible for Indonesia to submit any claims, the Australia may be well-prepared to response to any complaint from the Indonesian government. The Australian government has taken all measures required by the OPRC in mitigation the oil incidents. ${ }^{19}$ To this end, it may be difficult for Indonesia to seek remedies under the OPRC. Therefore, other means of dispute settlement should be taken into consideration.

\section{A. The International Court of Justice (ICJ)}

Based on Article 36(1) of the ICJ Statute, the Court has jurisdiction to all cases which the parties refer to it and all matters specifically provided for in the Charter of the United Nations or in treaties and conventions in force. The jurisdiction of the ICJ in all legal disputes concerning the the interpretation of a treaty, any question of international law, the existence of any facts which, if established, would constitute a breach of an international obligation or the nature or extent of the reparation to be made for the breach of an international obligation. ${ }^{20}$

States can accede to the jurisdiction of the Court in number of ways, both explisit and implicit. Before considering them individually, it is important to note that each is ultimately dependent upon consent. The States' consent need not have been given at the same time with the registration of the dispute, but must have been provided at some stage or the Court will be unable adjudicate the case. ${ }^{21}$

In relation to Montara case, State has obligation to prevent any pollution arising from incidents or activities under their jurisdiction or control does not spread beyond the areas where they exsercise its sovereign rights. ${ }^{22}$ In addition, when States have reasonable grounds to believe that the planned activities under their jurisdiction or control may cause substantial pollution of or significant and harmful changes to the marine environment, they shall assess the potential effects of such activities and shall communicate the results of such assessments. ${ }^{23}$

182000 Protocol on Preparedness, Response and Co-operation to Pollution Incidents by Hazardous and Noxious Substances, London, 15 March 2000, annex para. 1.

${ }_{19}$ Details on the Australian government actions may be found in Government of Australia, "Final Government Response to the Report of the Montara Commission of Inquiry" and Australian Maritime Safety Authority, "Response to the Montara Wellhead Platform Incident Report of the Incident Analysis Team."

20 Statute of the International Court of Justice, 18 April 1946, art. 36(2)(c) (d).

21 Stuart Kaye, "Peaceful Settlement of Disputes in International Law" in Public International Law: An Australian Perspective, edited by Slam Blay, Ryszard Piotrowicz and Martin Tsamenyi, (Oxford: Oxford University Press, 2005), p. 149.

22 Convention on the Law of the Sea (UNCLOS), Montego Bay, 10 December 1982, United Nations Treaty Series, Vol. 1833, No. 31363, art. 194(2).

${ }^{23}$ Ibid., art. 206. 
States shall take any measures necessary to ensure that activities under their jurisdiction or control are so conducted as not to cause damage by pollution to other States and their environment. In Montara case, Australia may be held responsible if it fails to take necessary measures to prevent the oil spill to enter into Indonesian water. There was uncontrolled release of hydrocarbons from one of the platform wells of Montara which allegedly has caused polution in Indonesian water. Therefore, Australia has violated its international obligation under the United Nations Convention on the Law of the Sea (UNCLOS) 1982.

Furthermore, an injured party can request evidence whether the oil drilling activity by Montara has obtained an environmental impact assessments approval from the Australian government. In its recent Pulp Mills on the River Uruguay (Argentina v. Uruguay) judgement, ${ }^{24}$ the ICJ acknowledged that:

It may now be considered a requirement under general international law to undertake an environmental impact assessment where there is a risk that the proposed industrial activity may have a significant adverse impact in a transboundary context, in particular, on a shared resource.

The Court added that "general international law (does not) specify the scope and content of an environmental impact assessment." It was the view of the Court that "it is for each State to determine in its domestic legislation or in the authorization process for the project, the specific content of the environmental impact assessment required in each case, having regard to the nature and magnitude of the proposed development and its likely adverse impact on the environment as well as to the need to exercise due dilligence in conducting such an assessment." The assessment should be done "prior to the implementation of a project" and "once operation have started and, where necessary, throughout the life of a project continuous monitoring of its effects on the environment shall be undertaken."

In accordance with the principle as stated in the Trail Smelter case ${ }^{25}$ that State may not use or allow its nationals to use its own territory in such a manner as to cause injury to a neighboring country. The Court held that Canada responsible for the conduct of the Trail Smelter and enjoined it to pay compensation to US. The Court also provided for future monitoring of the effects of the factory's activities on the environments.

Based on the Trail Smelter case and the Pulp Mills case above, coupled with the ICJ Statute, State parties to the ICJ Statute have the right to bring transboundary environmental pollution dispute under the ICJ jurisdiction, and the matter will be settled by the decision of the Court. Therefore, Indonesia is able to bring the Montara case before the ICJ is based on the allegation of the violation of Australia' international obligations under the UNCLOS 1982. However, the jurisdiction of ICJ can not be established if Australia refuses to bring the case before the Court. However, considering the past, current and future of Indonesia and Australia relations, there is less likely that both countries will give their consent to enable the ICJ to have its jurisdiction over the Montara case.

${ }^{24}$ International Court of Justice, Pulp Mills on the River Uruguay (Argentina v. Uruguay), Judgement, I.C.J. Reports 2010, p. 14.

${ }_{25}$ The Smelter Case (United States, Canada), International Arbitral Awards, United Nations Reports, 1941, p. 1965. 


\section{B. Litigation in Australian Court}

Apart from the possibility to bring this case to an international forum, there is also a possibility to bring this case to an Australian civil court. The main reason of employing this strategy is because the incident was occurred in Australian territory and the company operating the Montara Platform was established under the law of Australia.

Suing an Australian company for the negative impact of its operation overseas is not a new strategy taken by the victim of corporate abuse. Claims on violation of human rights by corporation can be a legitimate cause of action under Australian tort law. ${ }^{26}$ A few cases have been filed by foreign plaintiffs against Australian companies, and most of these cases have been settled out of court. The most notable case in Australia is the case against Broken Hill Proprietary Co. Ltd. (BHP), a giant Australian mining company.

In Dagi v Broken Hill Proprietary Co. Ltd., a legal action was brought by a number of Papua New Guinea landowners against BHP in the Supreme Court of Victoria. ${ }^{27}$ In this case, the plaintiffs alleged that BHP had continuously dumped mine tailing waste into the Ok Tedi River. This caused severe environmental damages to the river and destroyed the plaintiffs' way of life. ${ }^{28}$ In 1996, the plaintiffs and the defendant reached an agreement to settle the case. BHP offered monetary compensation and agreed to fix the environmental damages. However, another lawsuit was filed by the victims four years later in Gagarimabu v Broken Hill Proprietary Co. Ltd. ${ }^{29}$ wherein the plaintiffs claimed that BHP had breached the 1996 Ok Tedi Settlement Agreement. ${ }^{30}$ This case was dismissed in 2004. ${ }^{31}$

Establishing jurisdiction over an extraterritorial conduct of BHP was not a problem for the court in Dagi. As decided previously by the Supreme Court of New South Wales in the Renault ${ }^{32}$ case, Australian courts have jurisdiction if a nexus exists between the alleged conduct and Australia. ${ }^{33}$ One way in which to satisfy this requirement is if the damage incurred by the plaintiff was a consequence of wrongful conduct in Australia. ${ }^{34}$ Alternatively, a nexus is established if the corporate defendant conducts business in Australian territory. ${ }^{35}$ It was clear in Dagi that BHP is a corporation established and domiciled in the Australian jurisdiction. Likewise, the plaintiffs' claim concerned the

26 Oxford Pro Bono Publico, "Obstacles to Justice and Redress for Victims of Corporate Human Rights Abuse," (a comparative submission prepared for Professor John Ruggie, UN Secretary-General's Special Representative on Business \& Human Rights, Oxford, 3 November 2008), p. 9, http://www.lse.ac.uk/ collections/law/staff/webber/Oxford-Pro-Bono-Publico-submission-to-Ruggie-3-Nov-08.pdf, accessed 12 September 2014.

${ }^{27}$ Dagi v. BHP (1995) 1 VR 428.

${ }^{28}$ Joanna Kyriakakis, "Freeport in West Papua: Bringing Corporations to Account for the International Human Rights Abuses under Australian Criminal and Tort Law," Monash University Law Review Vol. 31 No. 1 (2005): 115.

${ }^{29}$ Gagarimabu v. Broken Hill Proprietary Co Ltd (2001) VSC 517 (SCt Vic).

30 Jonathan Drimmer, "Human Rights and the Extractive Industries: Litigation and Compliance Trends," Journal of World Energy Law \& Business Vol. 3 No. 2 (July 2010): 132.

${ }^{31}$ Sarah Joseph, Corporations and Transnational Human Rights Litigation (Oxford: Hart Publishing, 2004), p. 124.

${ }^{32}$ Regie Nationale des Usines Renault SA v. Zhang (2002) 210 CLR 491 (HCA).

33 Joseph, op.cit., p. 123.

${ }^{34}$ Ibid.

35 Ibid. 
direct involvement of BHP in the mining operation that caused the damage.

Therefore, learning from the Renault and the Dagi cases above, there is a possibility to file a legal suit against PTTEPAA in an Australian civil court. This is because there is a link between the oil spill incident in Australian territory and the alleged environmental damage in Indonesian territory. However, the problem in bringing the case to Australia court is not about establishing court jurisdiction. The possible barriers for the victims in bringing this case are relating to a number of technical matters, such as finding an appropriate lawyer to represent their interest, unfamiliar evidence and witness examination process, and financial concerns.

To this end, though there is a possibility that an Australian court may have jurisdiction to entertain the Montara case. However, plaintiff may potentially find technical barriers, and this may cause significant burden for victim in obtaining remedy.

\section{Litigating Montara Case in Indonesian Civil Court}

As article aims at seeking the possibility to bring Montara case to Indonesian civil court, there are three issues that have to be determined when discussing this possibility. These are: (1) on what legal basis that the case can be brought to a civil court and does the court has jurisdiction to entertain the case; (2) who should be the most appropriate plaintiff in this case; and (3) who should be the defendant in this case. Those issues will be discussed further in the next part respectively.

\section{A. Subject Matter Jurisdiction}

The Montara case involves environmental damage in the sea area. What makes this case different is its trans boundary characteristic. This pollution was caused by an incident that took place outside the Indonesian territory. The law on trans boundary pollution at the sea caused by drilling platform remains unclear. A number of international instruments regulating sea pollution cover issues on the civil liability of pollution by ships only. ${ }^{36}$ Unfortunately, there has been a lack of international rules on civil liability of a private entity in relation to sea pollution by an oil platform. Therefore, the most possible resort is the domestic laws.

There are a number of laws and regulations which regulate private party liability in relation to environmental damages. Unfortunately, only few law that may be applied to enforce private liability in Montara case. For instance, the Law on Indonesian Water is silent about the liability of private party in causing environmental damage to the sea water. ${ }^{37}$ Likewise, the Law on Fisheries only covers criminal liability to any person whose action has harmed the fish resources and its environment, but fall short in regulating the civil liability. ${ }^{38}$

Nevertheless, the Law regarding the Management of Coastal Area and Small Islands

36 These instruments include: The International Convention on Civil Liability for Oil Pollution Damage1969; The Convention on the Prevention of Marine Pollution by Dumping of Wastes and Other Matter 1972; The International Convention on Oil Pollution Preparedness Response and Cooperation 1990; and International Convention for the Prevention of Pollution from Ships 1973.

37 Indonesia (1), Undang-Undang tentang Perairan Indonesia ( Law regarding Indonesian Water), UU No. 6 Tahun 1996, LN No. 73 Tahun 1996 (Law Number 6 Year 1996, SG No. 73 Year 1960), art. 23.

38 Indonesia (2), Undang-Undang tentang Perikanan (Law regarding Fisheries), UU No. 31 Tahun 2004, LN No. 118 Tahun 2004 (Law Number 31 Year 2004, SG No. 118 Year 2004), art. 12(1) and 86(1). 
covers civil liability on environmental damages at the coastal area which caused by foreign activities. ${ }^{39}$ More specifically, private entity liability for polluting the sea water is regulated in the Government Regulation on the Control of Pollution and Damage at Sea. Private entity causing pollution to the sea must be liable to pay the rehabilitation of the environment and compensation for the damage suffered by the victims. ${ }^{40}$

In general, under the new Environmental Protection and Management Law (EPML) which was enacted in 2009, in cases in which environmental damage occurs, corporations have the obligations to: (1) take necessary action to end the damage, ${ }^{41}$ (2) restore the environment $\mathrm{t}^{42}$ and (3) deposit a fund for the process of environmental restoration. ${ }^{43}$ Likewise, the 'strict liability' rule of the EPML imposes an obligation on corporations to compensate directly and immediately for damages and losses caused to the environment. A firm may fall under the strict liability rule if its business activity causes a 'serious threat' to the environment, regardless of whether the element of fault exists. ${ }^{44}$

Finally, a corporation may be held liable in a civil court for its unlawful action. The Indonesian Civil Code provides that a person or a legal person committing an unlawful misconduct (perbuatan melawan hukum) that causes damage to another person must pay compensation for the loss sustained from that action. ${ }^{45}$ Furthermore, a person is liable for damages caused not just by his or her actions but also by his or her negligence and/or recklessness. ${ }^{46}$ Finally, a person is liable for the damages caused by the action of persons under his or her responsibility, and employers are liable for any damages caused by their employees or assistants in carrying out the duty for which they were employed. ${ }^{47}$

Based on the above laws and regulation, the occurrence of crude oil substance at the vicinity of Rote Island which allegedly caused damage to the environment and the livelihood of fishermen, is therefore may be brought before the civil court.

\section{B. Plaintiffs}

In relation to the question of who should bring the case to the court, there are at least three options: (1) the GOI; (2) Non-Governmental Organisation (NGOs); and (3) the victims. Therefore, there are three possible plaintiffs for the Montara case.

First, the GOI is able to file a legal suit against corporation based on its capacity

\footnotetext{
${ }^{39}$ Indonesia (3), Undang-Undang tentang Pengelolaan Wilayah Pesisir dan Pulau-pulau Kecil (Law regarding Management of Coastal Area and Small Islands), UU No. 1 Tahun 2014, LN No. 5 Tahun 2014 (Law Number 1 Year 2004, SG No. 5 Year 2004), art. 66.

40 Indonesia (4), Peraturan Pemerintah tentang Pengendalian Pencemaran dan/atau Perusakan Laut (Law regarding the Control of Pollution and Damage at Sea), PP No. 19 Tahun 1999, LN. No. 32 Tahun 1999 (Government Regulation Number 19 Year 1999, SG No.32 Year 1999), art. 24.

${ }^{41}$ Indonesia (5), Undang-Undang tentang Perlindungan dan Pengelolaan (Law regarding Environmental Protection and Management), UU No. 32 Tahun 2009, LN No. 140 Tahun 2009 (Law Number 32 Year 2009, SG No. 140 Year 2009), art. 53.

${ }^{42}$ Ibid., art. 54.

43 Ibid., art. 55.

44 Ibid., art. 88.

${ }^{45}$ Indonesia (6), Kitab Undang-Undang Hukum Perdata (Indonesian Civil Code), Staatsblaad No. 23 Year 1847, art. 1365.

${ }^{46}$ Ibid., art. 1336.

47 Ibid., art. 1367.
} 
as the governing authority of the state. ${ }^{48}$ It is the government's obligation to protect the environment and the interest of its people as mandated by the 1945 Constitution. There have been a number of cases where the GOI filed a case against corporation, particularly in environmental dispute. For example, in Buyat case, the Ministry of Environment (MoE) filed a case in a civil court against PT Newmont Minahasa Raya (PTNMR), alleging that the defendant had been polluting Buyat Bay. ${ }^{49}$ Based on the finding of its Joint Investigating Team, the MoE claimed that the dumping of tailings by PTNMR into Buyat Bay had caused pollution, which resulted in environmental degradation, the loss of livelihood sources and income for local fishermen, and health problems for the local residents. The MoE demanded PTNMR to pay USD117 million for rehabilitation and compensation, and another Rp150 billion for moral damages. The MoE based its claim on the 'strict liability' principle found in Article 35 of the 1997 Environmental Law, which provides that a corporation must be strictly held liable for damages resulting from its business operation. ${ }^{50}$

However, before a final and binding decision on this case could be rendered, both parties agreed to enter into an out-of-court settlement agreement. In this so called 'Goodwill Agreement', PTNMR agreed to pay US\$30 million to fund community development project and scientific observation in the Buyat Bay area. ${ }^{51}$ Unfortunately, there has been a lack of transparency on the use and the distribution of the compensation fund. The government has never been issuing any report on the fund.

Thus, learning from the Buyat case above, in the victims' point of view, perhaps the GOI should not be in the best position to be a plaintiff in Montara case. The lack of transparency in the government body and rampant corruption practices may hamper the victims' ability in obtaining redress.

Second, the environmental law provides a possibility for environmental NGOs to have legal standing and to appear before the court representing the environment. ${ }^{52}$ The Wahana Lingkungan Hidup Indonesia (WALHI) in particular, has been the most active NGO to bring lawsuits against corporations. There is one particular advantage in this mechanism. Compared to the victims, an NGO may have better ability and resources to conduct investigation, collecting evidence and preparing court documents.

However, this mechanism is not without limitation. A civil suit based on the legal standing of environmental NGO can only request the court to order the defendant to conduct certain activities, such as environment rehabilitation and preservation. The plaintiff is not allowed to request compensation for the damages. ${ }^{53}$ Therefore, this strategy may be appropriate to hold the company liable for damaging the environment, but less favourable for the victim to obtain remedy.

Third, the Indonesian environmental laws provide a possibility for the victims

${ }^{48}$ Indonesia (5), op.cit., Art. 90.

${ }^{49}$ District Court of South Jakarta (1), "Decision No. 94/Pdt.G/2005/PN.JKT.Sel."

50 Hukumonline (1), "MoE Uses Strict Liability Principle in Legal Suit Againts Newmont (KLH Menggunakan Dalil Strict Liability Dalam Gugatan terhadap Newmont)," http://www.hukumonline.com/ berita/baca/hol12637/klh-menggunakan-dalil-istrict-liability-dalam-gugatan-terhadap-newmont, accessed 22 January 2011.

${ }^{51}$ Hukumonline (2), "Amicable Agreement Between RI-Newmont, Regreted by Environmental Activist (RI-Newmont Damai, Aktivis Lingkungan Mengecam)," http://www.hukumonline.com/berita/baca/ hol14412/rinewmont-damai-aktivis-lingkungan-mengecam, accessed 22 January 2011.

52 Indonesia (5), op.cit., art. 92(1).

${ }^{53}$ Ibid., art. 92(2). 
to seek damage through class action suit. ${ }^{54}$ A group of people living in the specific area suffer from similar damage and has similar legal basis to suit, may file a suit using class action strategy. ${ }^{55}$ By employing class action, the victims are able to request compensation for the damage they suffer. ${ }^{56}$ They may calculate their loss occurred from physical injury or health problems, and loss of income.Based on the above discussion, perhaps this Montara case can be brought by two different plaintiffs in separate lawsuit. These are by the environmental NGOs and by the victims. A legal suit by the environmental NGOs is needed to determine the liability of PTTEP AA and PTTEP PCL. Once the court declares that these companies are liable for polluting the Indonesian water and coastal zone, it will open the way for the victim to seek compensation.

\section{Defendants}

It is possible to file a legal suit against foreign entity in Indonesian civil court. Filing a legal suit against entity for an action conducted overseas, which has impact in Indonesian territory, is possible. Perhaps, the best example to explain the possibility of suing foreign defendant is the Time Magazine case.

In the Time Magazine case, Soeharto, the former Indonesian President, filed a civil lawsuit at the Central Jakarta District Court against Time Inc. Asia, a company based in Hong Kong. ${ }^{57}$ The other defendant were Time Asia editor-in-chief Donald Morrison, Hong Kong bureau chief John Colmey, and reporters David Liebhold, Lisa Rose Weaver, Zamira Lubis and Jason Tedjasukmana.

The Soeharto family sued Time Asia Inc. for defamation over its May 24, 1999 (Asian edition) cover story, which reported that Soeharto had collected USD15 billion during his 32 years in power. The plaintiff demanded Rp189 trillion (USD17.18 billion) in compensation. The Time magazine claimed that Soeharto's fortune included a USD9 billion fund that was transferred from Switzerland to Austria only days after his resignation on May 21,1998. The alleged fortune also includes cash, stocks, corporate assets, jewelry and fine arts. Soeharto has repeatedly denied that he personally had any bank accounts abroad, and challenged the magazine to prove its claim. ${ }^{58}$

The panel of judges of the Supreme Court handed down its final decision in August 2007. The court found that Time Asia Inc. has tarnished the good name of former president Soeharto over a report in its issue, and fined the defendant IDR1 trillion, or equal to USD106 million. ${ }^{59}$ Two years later, the Supreme Court issued its 'special procedure of review' decision, which overturned its previous decision, and acquits

54 Ibid., art. 91.

55 Supreme Court of Republic of Indonesia, Peraturan Mahkamah Agung tentang Acara Gugatan Perwakilan Kelompok (Supreme Court Regulation regarding Procedures for Class Action Lawsuit), Perma No. 1 Tahun 2002 (Supreme Court Regulation Number 1 Year 2002), art 2.

56 The Jakarta Post (3), "Fishermen 'Suffer' as Oil Spill Compensation Delayed," http://www.thejakartapost.com/news/2011/05/28/fishermen-E2\%80\%98suffer\%E2\%80\%99-oil-spill-compensationdelayed.html, accessed 10 September 2014.

57 The Jakarta Post (4), “Soeharto Sues ‘Time’ magazine for US\$27 Billion,” http://www.thejakartapost.com/news/1999/07/06/soeharto-sues-time039-magazine-us27-billion.html, accessed 20 September 2014.

58 The Jakarta Post (5), “RI Court Acquits 'Time' in Soeharto Case," http://www.thejakartapost. com/news/2009/04/17/ri-court-acquits-time039-soeharto-case.html, accessed on 20 September 2014.

59 Supreme Court of Republic of Indonesia (1), “Decision No. 3215 K/PDT/2001,” p. 34. 
Time Asia Inc. from paying compensation. ${ }^{60}$ The Time Magazine case shows that Indonesia court may establish jurisdiction over a foreign defendant for its overseas action.

However, the Time Magazine case is not the only case where foreign entity is brought before the Indonesian civil court. Another case which also has foreign elements was the Pindo Deli case. In this case, PT. Pindo Deli Pulp and Paper Mills, a paper producers, established under Indonesian law, filed a legal suit against New Page Corporation and two other companies, all based in the United States of America. ${ }^{61}$

This case arose because the defendant filed a report to the US International Trade Commission and the US Department of Commerce alleged that the plaintiff has conducted dumping practice. In its report, the defendant argued that the plaintiff sells Coated Free Sheet papers in the US market at a price lower that it sells in Indonesia. The plaintiffs argued that the defendant's report was baseless, and was aimed to limit the selling of paper products coming from Asian countries in the US market. Therefore, the plaintiff brought the defendants to Indonesian civil court, alleging that the defendant's dumping report had created barrier for the plaintiff to export its paper product to the US. ${ }^{62}$

The panel of judges in the court of first instance handed down its judgment in favor of the plaintiff. The District Court of Central Jakarta found that the defendants violated the law, and therefore, should pay the plaintiff at USD9.439.674,17 as compensation. ${ }^{63}$ However, this decision was overruled by the High Court of Jakarta. Based on Article 100 Reglement op de Rechtsvordering (RV) ${ }^{64}$ of the Indonesian law on civil procedure, the High Court was in the opinion that it has no jurisdiction to adjudicate this case. The Article $100 \mathrm{RV}$ states that foreign defendant may be sued before Indonesian civil court only if a contractual relation between the foreign defendant and the Indonesian plaintiff exists. ${ }^{65}$ The Supreme Court upheld the above decision, and declared that the court has no jurisdiction to adjudicate this case.

Apparently, the Time Magazine case and the Pindo Deli case provide valuable lessons for the Montara case. There are at least two lessons that may be obtained from those cases, these are as explained below.

First, the Indonesian civil court may have jurisdiction over a foreign defendant if the defendant does not raise objection on the court jurisdiction. In another word, the foreign defendant voluntarily submits itself to the jurisdiction of the court. This situation occurred in the Time Magazine case. The Time Asia Inc. did not raise objection on court jurisdiction. The reason for this action may not be legal, but more to business reason. Perhaps, in the business calculation of the Time Asia Inc., responding to the Soeharto's claim in Indonesian court would be the best ways in keeping the sustainability of its business in Indonesia.

Second, a foreign defendant may be sued in Indonesian civil court only if there is a contractual relationship between the foreign defendant and the Indonesian plaintiff. In the Pindo Deli case, the court did not find any contractual relationship between the

\footnotetext{
${ }^{60}$ Supreme Court of Republic of Indonesia (2), "Decision No. 273 PK/PDT/2008."

${ }^{61}$ Supreme Court of Republic of Indonesia (3), “Decision No. 871 K/Pdt /2010,” p. 3.

${ }^{62}$ Ibid., p. 11.

${ }^{63}$ District Court of Central Jakarta, “Decision No. 98/Pdt .G/2007/PN.Jkt.Pst.”

${ }^{64}$ Indonesia (7), Reglement op de Rechtsvordering (Law regarding the Indonesian Civil Procedure), Staatsblad Year 1847 No. 52 jo. Staatsblad Year 1849 No. 63, art. 100.

${ }^{65}$ High Court of Jakarta, "Decision No. 27/PDT/2009/PT.DKI."
} 
parties in dispute. Under Indonesian civil law, a contractual relationship may exist in two ways: (a) contractual relationship created by contract/agreement between the parties; and (b) contractual relationship created by the law, so that any violations to the law may create an obligation to the violator to compensate. ${ }^{66}$

The central issue in the Pindo Deli case was the report filed by New Page Corporation on indication of dumping practice to the US authorities. Indonesia is a member of the World Trade Organisation (WTO), and has ratified the agreement to establish the WTO. ${ }^{67}$ Therefore, Indonesia is bound to follow rules and procedures covered under the WTO agreements. Under the WTO agreement, any indication of dumping practice may be reported to a government authority which assigned to examine such report. ${ }^{68}$ For these reasons, the foreign defendant in the Pindo Deli has acted in compliance with the law. Thus, since there is no violation to the law, contractual relationships between PT Pindo Deli and New Page Corporation cannot be established.

Learning from the Time Magazine and the Pindo Deli cases, perhaps the most possible defendant in the Montara case is PTTEP AA. The reason to put this Australianbased company as the main defendant is because it operates the Montara oil platform, and has acknowledged its responsibility for the well-head blowout incident. The next question would be: can PTTEP AA be brought to Indonesian civil court? Taking the Pindo Deli case as example, there has to be a contractual relationship between Indonesia plaintiff and PTEP AA. This is to satisfy the requirement of Article $100 \mathrm{RV}$ of the Indonesian civil procedures.

As mentioned above, contractual relationship between parties may exist when created by the law. In the Montara case, contractual relationship between the parties may exist because there has been a violation of law. The pollution of Indonesian sea with crude oil which came from the Montara platform is a violation of Indonesian environmental law. This violation created contractual relationship between PTTEP AA and the victims. By law, PTTEP AA is bound to pay compensation and to restore the environment. Moreover, the Indonesian environmental law adopts a 'strict liability' principle. This means, polluter is bound to compensate regardless of whether or not the element of fault exist. For this reason, Indonesian civil court may have jurisdiction over PTTEP AA.

After establishing jurisdiction over PTTEP AA, the next issue is how to bring PTTEP AA to appear before the Indonesian civil court. Apparently, there seems to be no force that could bring PTTEP AA to respond to the plaintiff legal suit in Indonesian court. PTTEP AA has no business interest in Indonesia, and it has no representative office, nor any assets in Indonesia. Therefore, the plaintiff should consider in adding a second defendant. Learning from the Time Magazine case, the foreign defendant will appear before the court, if it has substantial business interest in Indonesia.

The second defendant that may be brought in Montara case is PTTEP PCL. This

${ }^{66}$ Indonesia (6), op.cit., art. 1233 and 1353. See also Rosa Agustina, "Perbuatan Melawan Hukum" in Hukum Perikatan (Law of Obligations) editied by Rosa Agustina, et al. (Jakarta: Universitas Indonesia, Universitas Leiden, Universitas Groningen, 2012), p. 4, Tutik, Titik Triwulan, Pengantar Hukum Perdata di Indonesia (Jakarta: Prestasi Pustaka, 2006), p. 260. and P.N.H. Simanjuntak, Pokok-Pokok Hukum Perdata Indonesia. (Jakarta: Djambatan, 2009), p. 349.

67 Indonesia (8), Undang-Undang tentang Pengesahan Persetujuan Pembentukan Organisasi Perdagangan Dunia (Law regarding Ratification of Agrement Establishing The World Trade Organization), UU No. 7 Tahun 1994 LN No. 57 Tahun 1994 (Law Number 7 Year 1994, SG No. 57 Year 1994).

${ }^{68}$ World Trade Organization, Agreement on Implementation of Article VI of the General Agreement on Tariffs and Trade 1994, Marakesh, 15 April 1994, L336, art. 5. 
second defendant is a company established and registered under the law of Thailand, and is a government-owned company operating in oil and gas exploration. PTTEP PCL has interest in Indonesian territory. It has an Indonesian holding company, the PTTEP Indonesia Company Limited, which holds 100 percent shares in another four subsidiary companies which operating in petroleum exploration and production activity in Indonesia. These four companies are: PTTEP South Mandar Limited, PTTEP Sadang Limited, PTTEP Malunda Limited, and PTTEP South Sageri Limited. ${ }^{69}$

Any lawsuits against PTTEP PCL may bring disadvantages for its business in Indonesia. Litigation process would harm PTTEP PCL business reputation in Indonesia. Since the Montara case involves public interest, the government tends to involve. There is a tendency that the government will support the victims' interest in obtaining redress. As GOI has the authority to issue oil and gas operation permit, disobeying court's order to appear would not be the best option for PTTEP PCL.

Another reason in adding PTTEP PCL as second defendant is because PTTEP PCL own 100 percent of shares in PTTEP AA. It means that PTTEP PCL has a significant level of control upon the operations of PTTEP AA. Under the doctrine of 'piercing the corporate veil'-which is applied in Indonesia Company Law-a company may be held responsible for the misconduct of its subsidiary when the parent hold substantial degree of control in its subsidiary. Therefore, PTTEP PCL may also be hold responsible for the wrongful misconduct of PTTEP AA.

\section{Possible Barriers for Victims to Obtain Remedy: Establishing Causal Link}

Despite this possibility, invoking articles 1365 to 1367 of the Indonesian civil code in environmental cases is not without obstacles. In claiming remedies under these Laws, five elements must exist. First, there must be an action, either active or passive. Second, the action must be an unlawful act. It can be an act that violates laws, that violates the right of other persons as granted by laws, or that is against the legal obligation of the actor, or an act inconsistent with morality and with good practice in the society regarding the respect of others' rights. Third, there must be a fault. A fault exists if there is a deliberative action or negligence and if there are no legal exemptions to these actions. Fourth, there must be a damage suffered by the injured party. Finally, there must be a linkage between the unlawful action and the damage suffered by the plaintiff. ${ }^{70}$

Utilising civil court in Montara case would raise a number of problems, which is] establishing the causal link between the action and the damage. The court may use the strict liability rules, and disregard whether or not the element of fault existed. This will make it easier for the plaintiff in this case. However, the plaintiff should seriously consider two issues.

First, whether or not the oil substances which found in the waters of Pulau Rote off the coast of West Timor are identical with those of found in the Montara wellhead blowout location.

${ }^{69}$ PTTEP Australia (2), Establishment of PTTEP South Mandar Limited, PTTEP Sadang Limited PTTEP Malunda Limited, and PTTEP South SageriLimited,http://www.pttep.com/en/InvestorRelations_SETNotificationDetail.aspx?ContentID=667, accessed on 20 September 2014.

${ }^{70}$ M. Fuady, Unlawful Action: A Contemporary Approach (Perbuatan Melawan Hukum: Pendekatan Kontemporer) (Bandung: Citra Aditya, 2005), p. 10. 
Based on the scientific research conducted by Mukhtasor, it is found that using aromatic chemical content identification technology, the samples of oil contamination found in Timor Sea is 95 percent identical with the oil derived from the Montara platforms. ${ }^{71}$ Moreover, a 2010 report issued by the Montara Commission of Inquiry supports the finding of Muhktasor. It was found that there is evidence before the inquiry which indicated that hydrocarbons entered the Indonesian and Timor Leste waters to a significant degree. ${ }^{72}$ Despite these findings, the plaintiffs still need to provide the judges with convincing evidences. This task may not be easy, that is because PTTEP AA has been continuously asserted that the oil has never reached the Australian and Indonesian coast.

Second, whether or not the alleged damage, such as the decreasing number of fish catch and the contamination of seaweed farms in the Timor Sea have been the result of the Montara oil spill incident. There have to be a direct causal link between the oil pollution and the damage, and there are no other causes that may possibly contribute to the damage. This particular issue perhaps will be the most difficult for the plaintiff to prove.

This issue has been one of the significant burdens for plaintiffs when filing an environmental dispute in Indonesian court. In WALHI v. PTNMR, a civil action brought by an environmental NGO failed to hold PTNMR liable for polluting the Buyat Bay; the court opined that there was not enough evidence to show that mining pollution had caused the health problems to the local population and environmental damage. ${ }^{73}$ Likewise, in the mudflow disaster case, the judges stated that the central issue was determining the parties who should be held responsible for the mudflows. ${ }^{74}$

In adjudicating this case, the panel of judge relied heavily on the expert testimonies regarding whether the accident was caused by the failure of PT Lapindo Brantas Inc. as the operator of Brantas PSC to install special casing for the drilling equipment, or was caused by natural phenomenon-that is, in relation to the earthquake that happened a few days before the mudflow. After hearing all testimonies, the court decided that the mudflow disaster had been caused by natural phenomenon, and not caused by the company's drilling activity. Therefore, the corporate defendants could not be held responsible for the disaster. ${ }^{75}$

Similar challenge will also be faced by the plaintiff when bringing the Montara pollution case to Indonesian civil court. Perhaps it will be more difficult to find the causal link in this case. There have been significant changes to the environment and the daily life of the victims since the pollution took place five years ago. The environment may have been back to its normal condition. Pollution to the sea water may have long been disappeared. The physical injury and health problems may have been healed.

Therefore, the causal link between oil pollution and the damages will depend

71 Jaringnews, “Tragedi Montara Terlupakan, Mukhtasor: Desak Penelitian Komprehensif,"http:// jaringnews.com/internasional/asia/19492/tragedi-montara-terlupakan-mukhtasor-desak-penelitiankomprehensif, accessed 20 September 2014.

72 Emily Mitchell, "Five Years of Waiting for Investigation into Montara Oil Spill," https://www. lawyersalliance.com.au/opinion/five-years-of-waiting-for-investigation-into-montara-oil-spill, accessed on 21 September 2014.

${ }^{73}$ District Court of South Jakarta (2), "Decision No. 548/Pdt.G/2007/PN.Jak.Sel."

74 District Court of South Jakarta (3), “Decision No. 284/Pdt.G/2007/PN.Jak.Sel,” pp. 193-196.

75 Hukumonline (3), "Caused by Natural Phenomenon, Judge Rejects Walhi's Suit (Dinilai Akibat Fenomena Alam, Hakim Tolak Gugatan Walhi) http://www.hukumonline.com/berita/baca/hol18236/dinilai-akibat-fenomena-alam-hakim-tolak-gugatan-walhi, accessed 22 September 2014. 
heavily on scientific record, medical record, record on the decrease of fisheries products, and the local government records which were taken shortly after the oil pollution appeared. As time passed, there may be a question about the legitimacy and validity of those records. In short, establishing the causal link in Montara case would not be an easy task.

\section{Conclusion}

This article finds that that filing a lawsuit against PTTEP AA, the operator of the Montara Platform, may be possible. Article $100 \mathrm{RV}$ of the Indonesian civil procedure provide an opportunity to sue foreign entity when contractual relationship exist. In Montara case, contractual relationship exists because there is a violation to Indonesian law. This violation creates an obligation to PTTEP AA to compensate the victims and to restore the environment. Likewise, PTTEP PCL should also be brought in this case; his is mainly because PTTTEP PCL, the parent company of PTTEP AA, has a substantial business interest and assets in four subsidiary companies operating in Indonesia's oil and gas industry. This situation will force both PTTEP AA and PTTEP PCL to appear before the court and to respond the plaintiffs' claim.

Further, there are two possible lawsuits in this case. The first is lawsuit based on the legal standing of the environmental NGOs, and the second is lawsuit based on class action mechanism. However, there is one crucial challenge for the plaintiffs. They must establish the nexus between the damage suffered and the oil pollution incident. This challenge in particular would be the most difficult for the plaintiffs. Some evidences of damages may have disappeared, considering that five years have elapsed since the incident first took place. Nevertheless, lawsuit in Indonesian court is worth trying. It will provide case precedent in obtaining remedy for the victims of trans boundary environmental pollution in Indonesia.

\section{Bibliography}

\section{Legal Documents}

Convention on the Law of the Sea (UNCLOS). Montego Bay, 10 December 1982. United Nations Treaty Series. Vol. 1833. No. 31363.

Convention on Oil Pollution Response and Co-Operation (OPRC). London, 30 November 1990. United Nations Treaty Series. No. 51, 30 ILM 733.

Statute of the International Court of Justice. 18 April 1946.

Dagi v. BHP (1995) 1 VR 428.

District Court of Central Jakarta. "Decision No. 98/Pdt .G/2007/PN.Jkt.Pst."

District Court of South Jakarta. "Decision No. 94/Pdt.G/2005/PN.JKT.Sel."

District Court of South Jakarta. "Decision No. 284/Pdt.G/2007/PN.Jak.Sel."

District Court of South Jakarta. "Decision No. 548/Pdt.G/2007/PN.Jak.Sel."

Gagarimabu v. Broken Hill Proprietary Co Ltd (2001) VSC 517 (SCt Vic).

Indonesia. Kitab Undang-Undang Hukum Perdata (Indonesian Civil Code), Staatsblaad No. 23 Year 1847 Art. 1365.

Indonesia. Peraturan Pemerintah tentang Pengendalian Pencemaran dan/atau Perusakan Laut (Law regarding the Control of Pollution and Damage at Sea). PP No. 19 Tahun 1999. LN. No. 32 Tahun 1999 (Government Regulation Number 
19 Year 1999. SG No.32 Year 1999).

Indonesia. Reglement op de Rechtsvordering (Law regarding the Indonesian Civil Procedure). Staatsblad Year 1847 No. 52 jo. Staatsblad Year 1849 No. 63.

Indonesia. Undang-Undang tentang Pengelolaan Wilayah Pesisir dan Pulau-pulau Kecil (Law regarding Management of Coastal Area and Small Islands). UU No. 1 Tahun 2014. LN No. 5 Tahun 2014 (Law Number 1 Year 2004. SG No. 5 Year 2004).

Indonesia. Undang-Undang tentang Pengesahan Persetujuan Pembentukan Organisasi Perdagangan Dunia (Law regarding Ratification of Agrement Establishing The World Trade Organization). UU No. 7 Tahun 1994 LN No. 57 Tahun 1994 (Law Number 7 Year 1994. SG No. 57 Year 1994).

Indonesia. Undang-Undang tentang Perairan Indonesia ( Law regarding Indonesian Water). UU No. 6 Tahun 1996. LN No. 73 Tahun 1996 (Law Number 6 Year 1996. SG No. 73 Year 1960).

Indonesia. Undang-Undang tentang Perikanan (Law regarding Fisheries). UU No. 31 Tahun 2004. LN NO. 118 Tahun 2004 (Law Number 31 Year 2004. SG No. 118 Year 2004).

Indonesia. Undang-Undang tentang Perlindungan dan Pengelolaan (Law regarding Environmental Protection and Management). UU No. 32 Tahun 2009. LN No. 140 Tahun 2009 (Law Number 32 Year 2009. SG No. 140 Year 2009).

International Court of Justice. Pulp Mills on the River Uruguay (Argentina v. Uruguay). Judgement. I.C.J. Reports 2010.

New Page Corporation et. al. v. PT. Pindo Deli Pulp and Paper Mills (2009). Decision of the High Court of Jakarta No. 27/PDT/2009/PT.DKI.

Regie Nationale des Usines Renault SA v. Zhang (2002) 210 CLR 491 (HCA).

Supreme Court of Republic of Indonesia. Peraturan Mahkamah Agung tentang Acara Gugatan Perwakilan Kelompok (Supreme Court Regulation regarding Procedures for Class Action Lawsuit). Perma No. 1 Tahun 2002 (Supreme Court Regulation Number 1 Year 2002).

Supreme Court of Republic of Indonesia. “Decision No. 273 PK/PDT/2008.”

Supreme Court of Republic of Indonesia. "Decision No. 871 K/Pdt /2010."

Supreme Court of Republic of Indonesia. "Decision No. 3215 K/PDT/2001.”

The Smelter Case (United States, Canada). International Arbitral Awards. United Nations Reports, 1941.

World Trade Organization. Agreement on Implementation of Article VI of the General Agreement on Tariffs and Trade 1994. Marakesh, 15 April 1994. L336.

\section{Books}

Fuady, M. Unlawful Action: A Contemporary Approach (Perbuatan Melawan Hukum: Pendekatan Kontemporer). Bandung: Citra Aditya, 2005.

Joseph, Sarah. Corporations and Transnational Human Rights Litigation. Oxford: Hart Publishing, 2004.

Kaye, Stuart. "Peaceful Settlement of Disputes in International Law" in Public International Law: An Australian Perspective. Edited by Slam Blay, Ryszard Piotrowicz and Martin Tsamenyi. Oxford: Oxford University Press, 2005.

\section{Articles}

Agustina, Rosa. "Perbuatan Melawan Hukum" in Hukum Perikatan (Law ofObligations). Editied by Rosa Agustina, et al. Jakarta: Universitas Indonesia, Universitas 
Leiden, Universitas Groningen, 2012.Australian Maritime Safety Authority. "Response to the Montara Wellhead Platform Incident: Report of the Incident Analysis Team." Report by the Incident Analysis Team into the Response by the National Plan to Combat Pollution of the Sea by Oil and Other Noxious and Hazardous Substances, to the Montara Wellhead Platform Incident, March 2010, http://www.amsa.gov.au/forms-and-publications/publications/ montara_iat_report.pdf. Accessed 10 September 2014.

Drimmer, Jonathan. "Human Rights and the Extractive Industries: Litigation and Compliance Trends." Journal of World Energy Law \& Business Vol. 3 No. 2 (July 2010): 121-139.

Kyriakakis, Joanna. "Freeport in West Papua: Bringing Corporations to Account for the International Human Rights Abuses under Australian Criminal and Tort Law." Monash University Law Review Vol. 31 No. 1 (2005): 95-115.

Oxford Pro Bono Publico. "Obstacles to Justice and Redress for Victims of Corporate Human Rights Abuse." A comparative submission prepared for Professor John Ruggie, UN Secretary-General's Special Representative on Business \& Human Rights, Oxford, 3 November 2008). http://www.lse.ac.uk/collections/law/ staff/webber/Oxford-Pro-Bono-Publico-submission-to-Ruggie-3-Nov-08.pdf. Accessed 12 September 2014.

\section{Websites}

Australian Government Department of the Environment. "Montara Oil Spill." http:// www.environment.gov.au/topics/marine/marine-pollution/montara-oil-spill. Accessed 8 September 2014.

Hukumonline. "Amicable Agreement Between RI-Newmont, Regreted by Environmental Activist (RI-Newmont Damai, Aktivis Lingkungan Mengecam)." http://www.hukumonline.com/berita/baca/hol14412/rinewmont-damaiaktivis-lingkungan-mengecam. Accessed 22 January 2011.

Hukumonline. "Caused by Natural Phenomenon, Judge Rejects Walhi's Suit (Dinilai Akibat Fenomena Alam, Hakim Tolak Gugatan Walhi)." http://www. hukumonline.com/berita/baca/hol18236/dinilai-akibat-fenomena-alamhakim-tolak-gugatan-walhi. Accessed on 22 September 2014.

Hukumonline. "MoE Uses Strict Liability Principle in Legal Suit Againts Newmont (KLH Menggunakan Dalil Strict Liability Dalam Gugatan terhadap Newmont)." http://www.hukumonline.com/berita/baca/hol12637/klh-menggunakandalil-istrict-liabilityi-dalam-gugatan-terhadap-newmont. Accessed 22 January 2011.

Jaringnews. "Tragedi Montara Terlupakan, Mukhtasor: Desak Penelitian Komprehensif." http://jaringnews.com/internasional/asia/19492/tragedimontara-terlupakan-mukhtasor-desak-penelitian-komprehensif. Accessed on 20 September 2014.

Mitchell, Emily. "Five Years of Waiting for Investigation into Montara Oil Spill." https://www.lawyersalliance.com.au/opinion/five-years-of-waiting-forinvestigation-into-montara-oil-spill. Accessed on 21 September 2014.

PTTEP Australia. Establishment of PTTEP South Mandar Limited, PTTEP Sadang Limited PTTEP Malunda Limited, and PTTEP South SageriLimited,http://www. pttep.com/en/InvestorRelations_SETNotificationDetail.aspx?ContentID $=667$. Accessed on 20 September 2014.

PTTEP Australaia. "Fact Sheet: Government of Indonesia Compensation Claim." http:// www.au.pttep.com/media/20778/government\%20of\%20indonesia\%20 compensation\%20claim.pdf. Accessed 10 September 2014. 
Rigzone. "PTTEP Fined Over $\$ 500,000$ for Montara Oil Spill Disaster." http://www. rigzone.com/news/article.asp?a_id=120382. Accessed 11 September 2014.

The Jakarta Globe. "2009 Timor Sea Oil Spill : Just as Devastating as Gulf of Mexico." http://www.thejakartaglobe.com/archive/2009-timor-sea-oil-spill-just-asdevastating-as-gulf-of-mexico/. Accessed 8 September 2014.

The Jakarta Post. 'Fishermen 'Suffer' as Oil Spill Compensation Delayed." http://www.thejakartapost.com/news/2011/05/28/ fishermenE2\%80\%98suffer\%E2\%80\%99-oil-spill-compensation-delayed. html. Accessed 10 September 2014

The Jakarta Post. "RI Court Acquits 'Time' in Soeharto Case." http://www. thejakartapost.com/news/2009/04/17/ri-court-acquits-time039-soehartocase.html. Accessed on 20 September 2014.

The Jakarta Post. "RI to Make Formal Claim in Timor Spill." http://www.thejakartapost. com/news/2010/08/24/ri-make-formal-claim-timor-spill.html. Accessed 20 September 2014.

The Jakarta Post. "Soeharto Sues ‘Time’ magazine for US\$27 Billion." http://www. thejakartapost.com/news/1999/07/06/soeharto-sues-time039-magazineus27billion.html. Accessed 20 September 2014.

The Jakarta Post. "West Timor Sea Contaminated by Oil Spill." http://www. thejakartapost.com/news/2009/10/28/west-timor-sea-contaminated-oilspill.html. Accessed 15 September 2014. 